\title{
elyra
}

\section{o mundo é redondo}

\section{Marília Garcia}

hoje cedo

helicópteros voando

- você ouviu? um

som infernal estrelas

caindo do céu

em cima da cabeça

descendo à terra

as pontas viradas pra baixo

está ouvindo?

desde cedo

o som cada vez mais

perto

posso

encostar a mão

me viro e vejo

a sombra

hélices rodando

em

câmera

lenta

mas helicóptero

não tem hélice ela disse

o que gira se chama rotor:

sistema de asas rotativas 


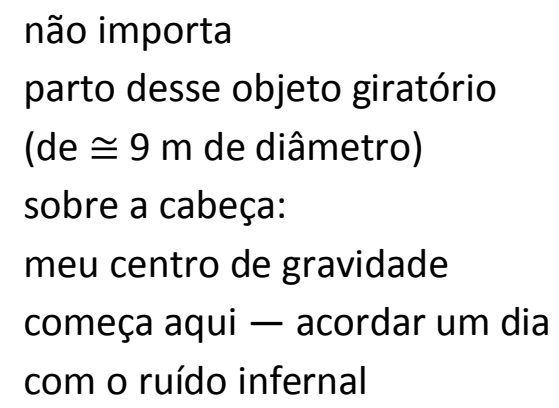


deixando um rastro pra trás

mas o ruído é de rotor

parado

suspenso no ar

pronto para despencar

como as estrelas

que descem à terra

neste dia

acordei com o som

dos helicópteros

e li uma frase:

há um ano ela olhava o mar dessa janela

neste dia

tentei ouvir

por trás do ruído

alguma mensagem

perdida

no ar

[as máquinas voadoras]

em 1480

leonardo da vinci começou a fazer

desenhos para máquinas

voadoras

uma delas se chamaria

la helice

e seu protótipo

era de um helicóptero

com hélice

a primeira demonstração 
de um voo de balão não-tripulado

ocorreu em agosto de 1709

em portugal

na corte de $d$. joão $v$

pela primeira vez

um objeto voador saiu do chão

para poder voar no século XVIII

era preciso ser mais leve

do que o ar

esses objetos voadores

eram chamados

de aeróstatos

ou máquinas aerostáticas

porque dentro delas

o ar ficava parado

como deveriam se sentir?

de repente não encostar mais

os pés no chão e alcançar o espaço

pela leveza

ver os balões e dirigíveis

subindo e ocupando o espaço

no século XIX

passam da aerostática

para a aerodinâmica

e começam os experimentos com

planadores

que pudessem ser mais pesados que o ar

e voar por meios próprios

os dirigíveis continuaram

se aperfeiçoando

e no começo do século XX

passaram a descrever trajetórias

mais precisas

chamam essa época de pioneira 
em 1901

santos dumont

contornou a torre eiffel

com seu dirigível $n .6$

o conde de zeppelin foi um militar alemão

inventor do dirigível com seu nome

em 1908 construiu um grande balão

que durante a primeira guerra

foi utilizado nos ataques aéreos

contra a bélgica

e a zona do canal da mancha

ele logo demonstrou

sua ineficiência

pela lentidão com que

se movia

há uma controvérsia

quanto ao primeiro voo bem-sucedido

de um avião tripulado

mas nessa história

registro apenas o santos dumont

na sua máquina $14-$ bis

que realizou em 1906

um voo de 220 metros

em paris

o primeiro voo bem-sucedido

de helicóptero também

ocorreu nos anos 1910

na frança

mas essa máquina

só alcançou a estabilidade

nos anos 1940

com fins militares

voltando aos voos não tripulados

chegamos ao drone

(que em inglês significa 


\section{zangão)}

ou "veículo aéreo

não tripulado"

são aviões controlados à distância

por meios eletrônicos

e computacionais

sob a supervisão humana

ou por meio de controladores lógicos

programáveis

[biossonar]

como as baleias

no fundo do mar

que se comunicam por meio

de ultrassons

os seres do ar

também emitem sons

de vários tipos

e podem captar

ondas lançadas

a muitos quilômetros

de distância

antonio tabucchi fala

de um tempo

em que as baleias

se comunicavam

das mais longínquas

posições do globo e

lançavam chamados amorosos

ou outros tipos de mensagens

cujo significado

nos escapa

também as ondas 
em trajetória pelo ar

são mensagens enviadas ao pavilhão auditivo

para comunicar

muitas vezes interceptamos

esses sons

mas não identificamos sua origem

um som também pode paralisar

mesmo sem termos entendido

o sentido

há um ano ela olhava o mar dessa janela

ele diz

e eu tento ouvir algo

por trás dos helicópteros

o ar está repleto de ruídos

mecânicos e de ondas artificiais

as mensagens sofrem um excesso

de interferências

para que possam

ser captadas e decifradas

se você

parar para ouvir

pode ser que

identifique algum

sinal

as baleias continuam

a lançar inutilmente

chamados

que vagam perdidos 